Journal of Humanities, Social and Management Sciences (JHSMS)

eISSN: 2788-4791 (online)

https://doi.org/10.47264/idea.jhsms/2.1.13

Vol. 2, No. 1 (January-June 2021), 147-165

https://www.ideapublishers.org/index.php/jhsms

Research Article

\title{
Portrayal of civil and military leadership of Pakistan: Content analysis of Newspapers of UK and USA during PPP regimes
}

\author{
Shahzad Ali | Ahmer Safwan | Muhammad Makkey Bhutta* \\ Department of Communication Studies, Bahauddin Zakariya University, Multan, Pakistan. \\ *Corresponding Author Email: makkey_k@ hotmail.com
}

Published: September 28, 2021

\begin{abstract}
Civil and military leadership of Pakistan have always played tremendous role in formulating and executing different policies regarding every issue of state. The significance of mainstream print media cannot be neglected as it forms public option regarding civil and military institutions in all countries. Therefore, the research has been designed to analyse portrayal of Pakistani civil and military leadership by four newspapers of the UK and the USA (Telegraph, Guardian, New York Times \& Washington Post) during tenures of PPP (1995-1996 \& 2008-2013). Quantitative content analysis has been adapted as research methodology to analyse features/articles, editorials and news stories in 9 major categories and 13 sub-categories with total 4053 published items in domain of civil \& military leadership of Pakistan regarding different issues of the tenures of Pakistan Peoples Party (PPP). Findings have divulged that British and American newspapers covered news stories against of military leadership of Pakistan especially in category of terrorism while greater pro-civilian coverage has been found in comparison of pro- military coverage in tenures PPP. Mr. Asif Ali Zardari has been covered with more negative representation before in power as compared to his regime as President of Pakistan. On the basis of cumulative representation in all categories, overall impression of Pakistan has been reflected negative and unfavourable in British and American Print Media.
\end{abstract}

Keywords: civilian leadership, military leadership, Pakistan, UK, USA, PPP, Benazir Bhutto, Asif Ali Zardari, media, representation, framing content, public opinion.

\section{How to Cite:}

Ali, S., Safwan, A., Bhutta, M. M. (2021). Portrayal of civil and military leadership of Pakistan: Content analysis of Newspapers of UK and USA during PPP regimes. Journal of Humanities, Social and Management Sciences (JHSMS), 2(1), 147-165. https://doi.org/10.47264/idea.jhsms/2.1.13

Publisher's Note: IDEA PUBLISHERS (IDEA Journals Group) stands neutral regarding jurisdictional claims in the published maps and institutional affiliations.

Copyright: ( 2021 The Author(s), published by IDEA PUBLISHERS (IDEA Journals Group)

This is an Open Access article published under the Creative Commons Attribution-NonCommercial 4.0 International License (http://creativecommons.org/licenses/by-nc/4.0/) 
Portrayal of civil and military leadership of Pakistan: Content analysis of Newspapers of UK ...

\section{Introduction}

The military leadership in all the societies of underdeveloped, developed and backwards regions has always been considered as most assertive, pivotal and major institution in comparison of other institutions of state because armed forces of respective country try their best possible efforts to indulge into defining, formulating and executing different policies either related with internal or external issues of state. Many underdeveloped countries believe on the notion that military leadership in the state has always kept itself away from identified roles \& functions that they were assumed to perform. Apparently, being considered as assertive institution, military leadership play tremendous role in challenging policies of civilian leadership in order to minimize and refuse their supremacy that may be resulted to weaken the ties of democracy (William, 2001). In this context, democracy in any state may be failed especially in underdeveloped counties because of facing problem in subordinating establishment under elected civilian institution. Consequently, the fight of acquiring this power between civil and military leadership result in frequency of military coups d'état (Huntington, 1995). Few scholars have contended that civil and military leadership has now been entered into new era in shape of modern wave of democracy and end of cold war, the ratio of successful military putsches would be lesser. The facts and figures of this era depict 30 to 40 attempts made by militancy in the time of 80's and 90's but their significant proportion was remained unsuccessful and military leadership got succeeded to have control over civilian government in the regions of Nigeria, Sudan, Haiti, Thailand and Pakistan (Berlin, 2001). As civilian leadership was damaged and become weaken due to nascent democratic experiments in these regions, plagued with long entrenched history of autocratic rule. But despite of all facts, it will be worth mentioning here to quote that military of coups of 19999 brought and eleven years revolution with substantial period of democratic rule.

\subsection{PPP Regimes in Pakistan}

Benazir Bhutto learned great political lessons from her first short tenure as her government survived only twenty months due to the differences and confrontation with president and the military establishment. In her second tenure, she was relatively more successful for establishing smooth relations with establishment as she refrained from meddling into professional affairs of the armed forces (Kaleem, 2015). There had been no difference between president and her regarding appointment of services chiefs. For instance, her government appointed General Jehangir Karamat as army chief on merit as he was the senior most of Lieutenant Generals as it was done first time in the political history of the country. The political leadership and intelligentsia appreciated Benazir Bhutto for the appointment of COAS on merit. Secondly, she supported the decision of army for ending the security operation in the province of Sindh in November 1994 in comparison of her provincial government, which was in favour of continuation. In return the establishment also supported her government for organizing Rangers, paramilitary force which has been playing a pivotal role in maintaining the law and order in the Province of Sindh in general and in metropolitan city of Karachi in particular (Shafqat, 1997). In addition to this, the civil and military leadership were on the same page with regard to foreign policy in the context of Afghanistan as Taliban emerged as new political force. She dealt and handled the issue aptly in accordance of interest of the establishment with blend of adequate mannerism (Haqqani, 2005). While on the front of governance she has been failed to perform well, bad governance, corruption, misuse of powers, economic mismanagement, appointment of political loyalists as superior judges was the reason which 
impaired her second tenure. President Farooq Ahmad Leghari expressed his displeasure over bad economic and law and order situation (Amin, 1994). It widens the gulf between the president and the prime minister. In this situation of political mistrust, General Jehangir Karmat intervene and tried to diffuse the collision between the president and the prime minister, but it proved fruitless as the president dismissed the government of Benazir Bhutto in November 1996 (Haqqani,2005).

In 2008, Mr Asif Ali Zardari, became elected president after resignation of General retired Pervez Musharraf, were projected by the mainstream print and electronic media of the country. Mr Asif Ali Zardari remained in the prison for more than eight years, but he was not declaring guilty in any case of corruption against him (Raza \& Akbar, 2012). It is pertinent to mention here that Benazir Bhutto returned to the country from the self-exiled after this NRO deal and was allowed to participate in political process as this agreement was brokered by the global key players from the United States and UK. Corruption charges were dropped against politicians and others under NRO deal which was brokered by USA between Musharraf and Benazir Bhutto which ultimately made it possible that she returned Pakistan from self-exile on October 18, 2007. Later course of events including imposition of emergency rule on November 3 and assassination of Benazir Bhutto on December 27, 2007 finally severally damaged him politically as his popularity was at its lowest ebb. Later on, his political party PML (Q) was defeated in the general elections of February 2008 as this defeat proved to be the last nail in the coffin of his political career. The new ruling political party PPP with support of other opposition parties forced him to resign from the presidency in August 2007 with the hovering sword of impeachment.

During the first tenure of General Ashfaq Pervez Kiyani as army chief and the first three years of PPP government under the leadership of President Asif Ali Zardari, the trust and relationship between civil-military institutions was comparatively more strengthened in comparison of previous governments of Benazir Bhutto or ZA Bhutto as army chief did earnest efforts by keeping army isolated from the politics. It was established that civil-military relations during the specific time period i.e., 2008 to 2013 had been keep oscillating from smooth, cordial to the incident based. For instance, the military establishment, civil society and mainstream political parties including oppositions in parliament by and large were on the same page as all the major stake holders develop a consensus on certain significant incidents namely closure of NATO supply route after the tragic incident of attack on Slala check post, Kerry Lugar bill, OBL killing and extension of army chief. While on Memo gate scandal, the military establishment was not at all pleased with the civilian leadership as they acted covertly and exerted pressure through Apex court (Kaleem, 2015). The establishment exerted pressure on civilian leadership for removing Hussain Haqqani, from the post of ambassador in the United States. Likewise, there were also differences between civilian and military leadership on the issue of diplomatic immunity of Raymond Davis. There has been a visible change in the stated position of the top brass of armed forces, as observed during the five-year term of PPP government (2008-2013). COAS General Kiyani and DG ISI briefed the members of the parliament. Precisely speaking, the relations between Civil and military leadership during this specific time period of the democratic regime in post Musharraf era were observed as oscillating from smooth to tense. In this connection, the government of Mr. Zardari was under tremendous political pressure due to the two significant incidents namely Memo gate scandal and Kerry Lugar Bill while the military establishment had to face criticism and were under pressure on OBL killing May 2011 through Operation Neptune Spear in Abbottabad. However, 
Portrayal of civil and military leadership of Pakistan: Content analysis of Newspapers of UK ...

both the civil and military leadership were on the same page as took unanimous decision by closing NATO supply route after the attack on Salala Check Post by the NATO. The supply route was reopened on issuance of official apology by the US secretary of the state (Kaleem, 2015). Historically speaking, the military leadership has been playing significant role as a key player by influencing all the policies irrespective of their domain.

\subsection{Statement of Problem}

There have been many researchers who divulged insights about coverage of Arab nationalism, Arab world and conflicting scenarios with Israel. Similarly, society of Middle East in domain of its culture and civilizations has been subject of many researches of media studies (Ghareeb, 1983; Suleiman, 1984). Portrayals of Pakistan have been covered in very few studies before 9/11 in which classical studies investigated editorial treatment of newspaper regarding IndoPak conflicts in context of issues of Kashmir (Sheikh, 1998). In the same era, many profound scholars have analysed portrayals of Muslim words in context of its culture and Islamization and produced quality studies on framing of Muslims, terrorism and clashes of civilization along with Islamophobia (Baker, 2010; Ghumman \& Ryan, 2013; Leskó, 2013; Semati, 2010). Few research studies were found on in context of drone attacks and military operations against Taliban in Pakistan (Ayoub \& Ahmed, 2013; khan \& Imran, 2011) but there is a need to study image of Pakistan in western media that cover issues of Pakistan on a larger scale. Therefore, the present research has owed to analyse representation of civil and military leadership of Pakistan in mainstream media of UK and USA during tenures of Pakistan People's Party (PPP) that comprised of the civilian leadership of Benazir Bhutto and Asif Ali Zardari as elected President of Pakistan.

\subsection{Significance of research}

The importance of this research can be analysed on several aspects in which most important is the geographical location of Pakistan which share border of Pakistan to Iran, Afghanistan, China, India and 700 miles coastline along with Arabian sea. Pakistan remains engaged with border countries in dynamics of trade and commerce that has significance in boosting economies of states. Thus, it can be said that importance behind this research is not limited to this study but for the rest of world having direct or indirect relation with Pakistan. Since independence, the relationship between political and military establishment of Pakistan has been remained central point of gravity for media persons and social scientists as history depicts many eras of military interventions and takeovers. Similarly, the impact of the western forces in influencing political, economic, military and foreign affairs of the country is no more a hidden secret as several studies have endorsed their interference in domestic and external spheres. By and large, the western powers specially the United States have supported the regime whosoever protected and worked for achieving their goals irrespective of democratic or autocratic governments. After 9/11 incident, world media again focused great attention of Pakistan while covering various issues related to war on terror. The military establishment of the country was blamed and maligned by the western media for sheltering OBL, Raymond Davis case, Memo gate scandal etc. Pakistan remained in the headlines of global media due to some pervasive and impact-oriented incidents including, corruption scam of key political leaders and stories bad governance. Therefore, it becomes significant to analyse image of Pakistani civil and military leadership in the era of PPP as results would unfold different frames in which Pakistan is being represented in Western Media. Theoretically, the results of this study 
would be going to fill gap left by research on similar paradigm in the past.

\subsection{Objectives of research}

The basic objectives of this research are:

- To analyse representation of civil and military leadership of Pakistan by mainstream British and American newspapers in both regimes of PPP.

- To investigate comparative portrayal of civilian leadership before in power, while in power and after in power in tenures of PPP.

- To analyse image of Pakistani civil and military leadership regarding issues of OBL, Memo gate, Kerry Logar Bill, Mumbai Attack and Raymond Davis

- To gauge overall impression of Pakistan by cumulative representation of civil and military leadership.

\subsection{Research questions}

The research questions of the study are:

- How the civil and military leadership of Pakistan was represented by mainstream British and American newspapers in both regimes of Pakistan Peoples Party?

- How civil leadership was comparatively portrayed before in power, while in power and after in power in the tenure of PPP?

- How the civil and military leadership were comparatively portrayed by the selected newspapers in context of issues namely OBL, Memo gate, Kerry Logar Bill, Mumbai Attack and Raymond Davis?

- What type of overall image of Pakistan has been created by collective representation of civil and military leadership?

\subsection{Hypothesis}

$\mathrm{H}_{1}$ : The military leadership is more likely to get negative coverage than civil leadership during regime of Pakistan Peoples Party.

$\mathrm{H}_{2}$ : It is more likely that pro civilian coverage will be greater as compared to supportive representation of military leadership.

$\mathrm{H}_{3}$ : Benazir Bhutto on her second term premier would be portrayed in more unfavourable frames in comparison of her self-exile phase.

$\mathrm{H}_{4}$ : Mr Asif Ali Zardari would receive more negative representation before in power as compared to while his five-year term as elected president of the country.

$\mathrm{H}_{5}$ : The military establishment would be represented more in negative tone in comparison of civilian leadership in the category of Terrorism.

$\mathrm{H}_{6}$ : The overall representation of Pakistan would be more negative on the basis of cumulative critical representation of civil and military establishment in the four selected newspapers of the UK and the US during both regimes of PPP.

\section{Literature review}

Before the incident of $9 / 11$, there have been found limited research studies on representation of Islam and Muslims in Western media while after this incident, there have been many 
Portrayal of civil and military leadership of Pakistan: Content analysis of Newspapers of UK ...

classical studies by scholars in domain of Islam and terrorism issues of Pakistan in quantitative context. Abidullah (2003) advocated the viewpoint and argued that mainstream print media with special reference to Newsweek magazine negatively propagated against the authenticity of Holy Quran and were disseminating hate speech contents against Islam, Muslims and Islamic world. Munoz (2005) stated that western media has given more preference by projecting negative symbol about Muslims, beard for men and veil for women, tried to paint these symbols in ideological context, and framed these images by bracketing with fundamentalism and such men and women were depicted as fundamentalists. Zundel (2005) also argued that Muslim world in general and Arab world in particular was framed a danger for the peace and stability of the region. In addition to this, he analysed two-year news and pictorial representation of Muslim women in Spanish print media. It was found that out of 332 pictorial images of Muslim women, one-third photographs were appeared with hard news items with negative image while two third images were published in inside pages, however less than one fifth pictorial images of Muslim women were published on front page of the mainstream newspaper of Spain. Sheridan (2006) argued that major world event of terrorism was the contributing factor for prejudice, discrimination against minorities and also effected the stereotypes. As the findings were based on analysis of 222 sample of British Muslims those reported about racial and religious discrimination. It was found that ratio of reported racial and religious discrimination in context of Islamophobia cases were found significantly greater in post September eleven phase in comparison of prior stage was increased as many as 76 percent respondents faced overt discrimination while more than one third had suffered mental health problems during post September eleven phase. Ruigrok and Atteveldt (2007) argued that British and Dutch mainstream newspapers considered proximity while selecting incident about terrorism. It was found that the media of both the countries framed these incidents in similar manner in light of global event of September eleven instead of local consideration.

The western media has been paying great attention to the coverage of Pakistan in the context of Taliban, Al Qaida, OBL and above all her role as an ally of the US in fight against extremism since September eleven, 2001. Several studies have so far been conducted specifically focusing on portrayal of Pakistan in the western mainstream print media; as most of the research projects were theoretically linked with agenda setting, framing theory, Shoemaker and Rees theory, Manufacturing consent, media conformity theory and Propaganda model of Herman and Chomsky. Several studies in pre and post September eleven scenario with regard to representation of Pakistan and other Muslim countries argued that they were portrayed with negative tone with overall unfavourable image of the Muslim world in contextual perspective by the mainstream Western and American print and electronic media (Ali \& Khalid, 2008). Siraj (2007) in his post-doctoral research study on news framing of Pakistan in American mainstream print media concluded that overall ratio of favourable coverage of Pakistan was found greater in Post September eleven period in comparison of pre- 9/11 period. He argued Pakistan received more unfavourable coverage in pre-September eleven period. Sheikh (1995) in his research article based on image of Iran in the Western media concluded that the US media cultivated negative image of Iran in minds of the readers by portraying her as an extremist, and a fundamentalist country with anti US stance. He identified the main reason behind the negative portrayal of Iran was her "Islamic Character" which was presented as a menace to regional peace as well as threat to the interests of America and Israel. Likewise, in his several other research articles on the issues like portrayal of Kashmir conflict; Foreign Affairs, Coverage of the Case of United States Media; image of Pakistan; framing of fundamentalism and other related issues of Muslim world explored these issues in the context 
of American foreign policy. The crux of his findings highlighted that the Muslim world was framed in unfavourable manners and the US mainstream media considered the foreign policy principles as a yard stick while covering and representing Islam and Muslim world (Sheikh, 1991; 1997).

Narayana and Kapur (2011) concluded that English newspapers of India covered the Gujrat riots while using more positive and favourable frames in support of Muslims while communal language media used more negative frames. Safdar et al. (2014) concluded that British mainstream press sided the policy of UK government in the context of Afghanistan war in 2001. The media criticized the policy of 10 Downing Street with the sphere of Iraq war. However, overall, the British media didn't toe the foreign policy while covering the war on terror. Carr and Haynes (2015) stated that Muslims were caught in conflict of racialism as antiMuslim racism was significantly increased in Ireland especially after terrorist attacks in London and Madrid. Falkheimer and Olsson (2015) argued that the Norwegian media constructed the news story of terrorist attack in Oslo and the Island of Utoya in 2011 in depoliticized manner as it was described an act of lunatic individual instead of linking it the with extremism of right-wing group.

Several studies have divulged that western media represented Muslim women in light of western collective memory as it has been perpetuated historically and the cultural imaginaries painted the image of Muslim women through specific dressing code. They were depicted in the veil, which was personified as symbol of oppression, and the society and leadership were critically held responsible for it. The western media constructed the irresponsible generalized image of Muslim women by ignoring the diversification and multi-dimensional other aspects related to different Muslim countries. It resulted in stereotypical representation of Muslim women in Hijab or veil and constructed as oppressed and inferior entity (Gilewicz, 2012; Hasan, 2007; Lakhani, 2008). While a study on representation of Muslim males, Syed (2009) argued that mainstream media presented distorted identity of male Muslims by creating fear of bearded Muslims in stereotypic way. They were portrayed as jihadist and terrorists particularly in post September eleven phase. The negative connotations with pejorative phrases were used while depicting image of Muslim women as oppressed and conservative entity (Mora, 2013). Milinković (2015) focused on representation of Muslim women in the digital British and American media in post September eleven context in the mirror of gender and feministic theory. It aimed to explore the ultimate consequences on social construction of reality and media representation through epistemology. It argued that most of the Muslim women in traditional society were suppressed with images of veil or hijab as they were living in male dominating world. It further explored that representation of liberal Muslim women was found different from the traditional one. Rasul and McDowell (2015) argued that global media didn't covered the plight of Afghan women living in countryside while national and international media intermittently focused on women of urban areas under the control of Afghan security agencies and coalition forces.

\section{Theoretical framework}

Theoretically, the study is associated with propaganda model of Herman \& Chomsky and shoemaker \& Stephen D'Reese of effect of content and especially focus on effect on news content which is produced due to policies of Government about Pakistan in Western Media. Number of studies in domain of Muslims, Islam endorsed concept of Chomsky and Reese's 
theory of content effect confirms solid ground through which Western and European media cover international issues in order to portray pictures of people and communities regarding foreign policies which is probably determined by the people of White House and 10 Dowing Street (Dorogi, 2001).

The study would determine and analyze the content that that British and American media presents about civil and military leadership of Pakistan and this media comprised of their mainstream print media including The Telegraph, Guardian, New York Times and Washington Post. Representation of Pakistan will be analyzed in different contexts and incidents which has been occurred during regimes of Benazir Bhutto and Mr. Asif Ali Zardari. The concept of framing of Media was advanced by Entman (1993) by consideration in the extension of agenda setting theory. Entman (1993) contended that framing of information by media direct affect thinking of readers of viewers. Raza and Akbar (2012) concluded that the News and daily Dawn, mainstream leading English newspapers of Pakistan constructed negative image of President Asif Ali Zardari. Through discourse analysis of leading articles with special reference to the News International, it was explored; his persona was painted as black sheep, corrupt, criminal and the most undesirable leader in the eyes of Pakistani public. The overall tone of the editorials of the News was negative, aggressive and based on condemnation of Mr Zardari as president in the context of NRO case while daily Dawn adopted neutral policy while discussing the role of Mr President with lesser negative connotation and metaphors. Finally, the News portrayed Mr Zardari as the beneficiary of NRO while on the other hand the leading and largest circulated English newspaper of Pakistan i.e. daily Dawn built up the discourse of the issue purely a system specific with blend of objectivity and neutrality. Ali et al. (2013) argued that Newsweek and Time, both the leading magazines of the United States portrayed Pakistan with negative connotation as the findings were based on qualitative and quantitative analysis of 128 articles about Pakistan in the context of terrorism, politics, economy and military operations.

\section{Methodology}

The research has been derived on quantitative paradigm and content analysis has been employed to conduct this research that facilitated to analyse coverage and the representation of civil and military leadership of Pakistan in British and American print media during regimes of Pakistan Peoples Party (PPP) from 1995 to 1996 (Benazir Bhutto tenure) and September 2008 to 2013 which is tenure of Mr. Asif Ali Zardari as elected President of Pakistan. The research has investigated about what sort of image British and American media has created about civil and military leadership in these tenures of PPP.

\subsection{Population and sampling of research}

The research has analysed by line stories, news, features/articles that have been written in context of civil and military leadership of Pakistan in four selected newspapers of UK and USA which comprised of The Telegraph, Guardian, New York Post and Washington Times during both tenures PPP leadership in Pakistan about nine major and 13 sub-categories. The reason of selection of these newspapers was their readability as they are considered as elite newspapers in both UK and USA. The content (publications) of these newspapers have been collected from the electronic database of Lexis-Nexis through using multiple keywords i.e., Army, General Kiayani, Pakistan, Political leadership, ISI, corruption, Asif Zardari, Benazir Bhutto etc. Total 
population of all published editorials and opinion articles in 9 major categories was 4053 in tenures PPP and out of total population, 259 items have been selected through purposive sampling technique in light of 13 sub-categories.

\subsubsection{Major categories}

By initial reading of newspapers, the content was assessed about political and military leadership in four selected newspapers that facilitated to sort out unit of analysis. All published items have been divided into two sections (categories and sub-categories). Following are major categories have been made on the basis of initial assessment.
a. Asif Ali Zardari
b. Benazir Bhutto
c.
Corruption
d. Democracy
e. General AshfaqPervaiz Kiyani
f. Human rights
g. Imran Khan
h.
Terrorism
i. Inter-services intelligence (ISI)

\subsubsection{Sub-categories}

In context of above broader categories, sub-categories/themes have been established to analyse the content, these sub-categories have been mentioned below:

\begin{tabular}{|l|l|l|l|c|l|}
\hline 1. & Corruption & 2. & Relations with United States & 3. & Relations with India \\
\hline 4. & Memo Gate & 5. & Relations with UK & 6. & Exile phase of leadership \\
\hline 7. & Kerry Logar bill & 8. & Raymond Davis case & 9. & Closure of NATO supply \\
\hline 10. & Mumbai attack & 11. & Attack on Salala check post & 12. & Political leadership \\
\hline 13. & Missing person's case & & & & \\
\hline
\end{tabular}

\section{A. Military leadership}

According to the selected tenure in this research, General Ishfaq Pervaiz Kiyani and InterServices intelligence (ISI) have been placed under the category of military leadership of Pakistan.

\section{B. Civilian leadership}

The civilian leadership of Pakistan Peoples Party's regimes comprised of two prominent personalities named as Benazir Bhutto during her second term as premier in 1995- 1996 and Mr. Asif Ali Zardari as elected President of Pakistan from 2008-2013.

\subsection{Unit of analysis}

There have been three units of analysis have been selected of the published content to analyse representation of civil and military leadership of Pakistan in print media of UK \& USA and these are comprised of news stories, articles/features and editorials. Furthermore, paragraphs in above units have been selected to gauge portrayal of civil \& military leadership in the context of positive, negative and neutral slants that systematically considered to have final assessment 
Portrayal of civil and military leadership of Pakistan: Content analysis of Newspapers of UK ...

about analysing overall representation of Pakistan by taking 6-frames on contextual grounds.

\subsubsection{Pro military leadership}

In this category, all by-line stories, articles/features and editorials were included that acknowledged role of military establishment of Pakistan in the mirror of positive light in order to maintain peace in this region, so these publish items have been portrayed as pro-militancy.

\subsubsection{Anti-military leadership}

It comprised of the published articles/features, by-line stories and editorials that intend to draw negative image of Pakistan military that furthermore depicted as sympathizer of terrorist organizations i.e., TTP, Taliban etc.

\subsubsection{Neutral to military leadership}

Under this mirror, all those published contends related with military leadership and intelligence agencies have been included that that does not portray them as positive or negative in context of their professional role in different domains of war on terror, relationships with civilian government as well as other allied sub-categories framed as natural stories.

\subsubsection{Pro civilian leadership}

All news items that represented elected civilian leadership of Pakistan in positive light in context of representing them as a tool of good governance, visions to set goals for leading country towards prosperity and modernization as well as development processes.

\subsubsection{Anti-civilian leadership}

This aspect represents about all those stories that depicted civilian leadership of Pakistan as money launderer, corrupt, kickbacks, held responsible for embezzlement as well as favouritism and dodgy in the mirror of negative tone.

\subsubsection{Neutral to civilian leadership}

All selected genres have been considered under this aspect that does not portray Pakistani civilian leadership either in positive or negative light which means that no positive or negative attributes are related to them.

\subsection{Framing of Pakistan}

According to the above-mentioned frames, overall impression of Pakistan has been considered to be reflected in light of civil and military leadership representation. The impression of Pakistan has analysed into three categories given below:

\subsubsection{Favourable}

All pro military and pro civilian by-line stories, features and editorials have been considered 
as yardstick to evaluate overall impression of Pakistan that would depict it image of Pakistan in positive light.

\subsubsection{Unfavourable}

All published items, which have been found against Pakistani civilian and military leadership, have been selected as determinant to gauge image of Pakistan under the analysis of unfavourable frame.

\subsubsection{Neutral}

All news items which do not have significant role to portray civilian and military leadership of Pakistan either in positive or negative sense have been adopted as yardstick to evaluate overall neutral image of Pakistan.

\subsection{Data analysis}

All by-line stories, opinion articles/features, editorials have been divided into different categories, and data has been entered into SPSS that generated results in the shape of descriptive statics, summary statistics and cross tabulation of variables according to objectives of this research.

\section{Results and discussion}

The table-1 represents overall representation of civil and military leadership in regimes of Pakistan Peoples Party (PPP) and figures reflect that anti-military leadership was found greater in Zardari's regime out of total $253(97.5 \%)$ news items. It is interesting to mention here that more than one third of items in favour of civilian leadership were published during the both term of Pakistan Peoples Party with ratio of 40 (15.4\%) out of total sampled frame $259(100 \%)$ of these regimes as mentioned in third column of the table. On the similar pattern more than one third anti-civilian representation (36.7\%) was found in era of Asif Ali Zardari (34.8\%) while $5(1.9 \%)$ anti civilian representation has been calculated in second term of Benazir Bhutto as a premier. Overall, more news items were found in the era of Mr. Zardari in comparison of second term of Benazir as a premier.

Table-1: Representation of civil and military leadership in PPP regimes

\begin{tabular}{|l|c|c|c|}
\hline \multirow{2}{*}{$\begin{array}{l}\text { Representation of civil } \\
\text { and military leadership }\end{array}$} & \multicolumn{3}{|c|}{ Pakistan Peoples Party regimes } \\
\cline { 2 - 4 } & $\begin{array}{c}\text { Asif Zardari term as } \\
\text { President N(\%) }\end{array}$ & $\begin{array}{c}\text { Benazir's second term } \\
\text { as Premier N(\%) }\end{array}$ & Total N(\%) \\
\hline Pro military leadership & $4(1.5)$ & $0(0)$ & $4(1.5)$ \\
\hline Anti-military leadership & $105(40.6)$ & $0(0.0)$ & $105(40.6)$ \\
\hline Neutral to military leadership & $2(0.8)$ & $0(0)$ & $2(0.8)$ \\
\hline Pro civilian leadership & $40(15.4)$ & $1(0.4)$ & $41(15.8)$ \\
\hline Anti-civilian leadership & $90(34.8)$ & $5(1.9)$ & $95(36.7)$ \\
\hline Neutral to civilian & $12(4.63)$ & $0(0.0)$ & $12(4.6)$ \\
\hline leadership & $253(97.5)$ & $6(2.33)$ & $259(100.0)$ \\
\hline Grand Total & & &
\end{tabular}


Portrayal of civil and military leadership of Pakistan: Content analysis of Newspapers of UK ...

The results in table-2 demonstrate that out of 259 (100\%) sampled news items, $253(97.7 \%)$ items were published in the tenure of Mr. Zardari when he was in power and serving as President 250 (96.6\%). The phase of coverage has been calculated greater when both Mr. Zardari and Benazir Bhutto were in power during their premier. It is interesting to note that only $1(0.3 \%)$ news item was found in Benazir Bhutto's regime in phase of before in power and no item was found in same phase related with Mr. Zardari. Contrary to this fact, $3(1.1 \%)$ representation of Asif Ali Zardari has been found in UK and US newspaper during phase of after completion of his regime as President of Pakistan.

Table-2: Phase of coverage in British and American Newspapers during PPP regimes.

\begin{tabular}{|l|c|c|c|c|}
\hline \multirow{2}{*}{ Regime } & \multicolumn{4}{|c|}{ Phase of coverage in the UK \& the US newspapers } \\
\cline { 2 - 5 } & $\begin{array}{c}\text { Before in power } \\
\mathrm{N}(\%)\end{array}$ & $\begin{array}{c}\text { After dismissal / resignation / } \\
\text { completion N(\%) }\end{array}$ & $\begin{array}{c}\text { While in } \\
\text { power N(\%) }\end{array}$ & Total N(\%) \\
\hline $\begin{array}{l}\text { Asif Ali Zardari tenure as } \\
\text { President }\end{array}$ & $0(0.0)$ & $3(1.1)$ & $250(96.6)$ & $253(97.7)$ \\
\hline $\begin{array}{l}\text { Benazir Bhutto's second } \\
\text { term as premier }\end{array}$ & $1(0.3)$ & $0(0.0)$ & $5(1.9)$ & $6(2.3)$ \\
\hline Total & $1(0.3)$ & $3(1.1)$ & $255(98.5)$ & $259(100.0)$ \\
\hline
\end{tabular}

The figures in table-3 reflect representation of civil and military leadership of Pakistan in nine major categories. Out of total sampled news, more than one-third representation was found on the subject of Asif Ali Zardari 98 (37.8\%). Second highest representation has been found in British and American mainstream newspaper related with Benazir Bhutto with 43 news items. Third highest coverage to was given to military leadership in the category of ISI (inter-services intelligence) but news related with General Kiyani was found in very less ratio of 4 (1.5\%). It is pertinent to mention here that 25 news items have been covered in the category of terrorism for civil and military leadership in British and American print media where as other major subjects of Imran Khan, human rights, democracy, corruption and terrorism were found with ratios of $3.0 \%, 4.6 \%, 5.0 \%, 9.2 \%$ and $9.6 \%$ respectively.

Table-3: Major subject-wise civil \& military leadership representation in PPP regimes

\begin{tabular}{|l|c|}
\hline Major Categories & Civil \& military leadership representation N(\%) \\
\hline Asif Ali Zardari & $98(37.9)$ \\
\hline Benazir Bhutto & $43(16.6)$ \\
\hline Corruption & $24(9.2)$ \\
\hline Democracy & $13(5.0)$ \\
\hline General Kiyani & $4(1.5)$ \\
\hline Human Rights & $12(4.6)$ \\
\hline Imran Khan & $8(3.0)$ \\
\hline ISI (Inter-services intelligence) & $32(12.3)$ \\
\hline Terrorism & $25(9.6)$ \\
\hline Total & $259(100)$ \\
\hline
\end{tabular}

Out of 98 selected samples about the subject of Mr. Asif Ali Zardari, 19.3\% of the coverage was found against of civilian leadership. If we analyze anti-civilian coverage in the context of these nine major categories, more than one third representations have given in British and American newspapers. Similarly, in the category of Benazir Bhutto, more anti-civilian 
coverage has been divulged that comprised of 20 news items out of 43 . More than one third representation has divulged against military leadership with ratio of $36.2 \%$ items in all categories. As far as the category of human rights is concerned, the military establishment was held responsible as culprit with poor and pathetic human rights records, as 2.3 percent article with frequency of 6 items out of 12 total sample frame was focused on anti-military contents in the four selected mainstream newspapers. In addition to this, military establishment was framed as rogue army and notorious spy agency plus officials by these newspapers as more than $10.4 \%$ percent items were negative out of 12.3 percent items in this category on contextual grounds with regard to coverage of Inter- Services Intelligence. Among the military leadership, General Ishfaq Parveiz Kiyani was represented in frame of neutral military leadership with ratio of 3 out of total 4 news items in this category whereas the subject of terrorism has been represented in context of anti-military leadership with 4.6 percent coverage out of 96 percent in this category. It is worth mentioning here that of we analyze through the context of procivilian coverage, both Mr. Asif Zardari and Benazir Bhutto has been framed positively with ratios of 8.1 percent and 3.8 percent respectively.

Table-4: Major subject wise representation of civil \& military leadership

Representation of civil and military leadership

\begin{tabular}{|l|c|c|c|c|c|c|c|}
\hline $\begin{array}{l}\text { Subjects of the } \\
\text { published items }\end{array}$ & $\begin{array}{c}\text { Pro } \\
\text { military } \\
\mathrm{N}(\%)\end{array}$ & $\begin{array}{c}\text { Anti- } \\
\text { military } \\
\mathrm{N}(\%)\end{array}$ & $\begin{array}{c}\text { Neutral to } \\
\text { military } \\
\mathrm{N}(\%)\end{array}$ & $\begin{array}{c}\text { Pro } \\
\text { civilian } \\
\mathrm{N}(\%)\end{array}$ & $\begin{array}{c}\text { Anti- } \\
\text { civilian } \\
\mathrm{N}(\%)\end{array}$ & $\begin{array}{c}\text { Neutral to } \\
\text { civilian } \\
\mathrm{N}(\%)\end{array}$ & $\begin{array}{c}\text { Total } \\
\mathrm{N}(\%)\end{array}$ \\
\hline Asif Ali Zardari & $1(0.4)$ & $26(10.0)$ & $0(0.0)$ & $21(8.1)$ & $50(19.3)$ & $0(0.0)$ & $98(37.9)$ \\
\hline Benazir Bhutto & $1(0.4)$ & $11(4.2)$ & $1(0.4)$ & $10(3.8)$ & $20(7.7)$ & $0(0.0)$ & $43(16.6)$ \\
\hline Corruption & $2(0.7)$ & $3(1.1)$ & $0(0.0)$ & $1(0.4)$ & $18(6.9)$ & $0(0.0)$ & $24(9.2)$ \\
\hline Democracy & $3(1.1)$ & $8(3.0)$ & $0(0.0)$ & $2(0.7)$ & $0(0.0)$ & $0(0.0)$ & $13(5.0)$ \\
\hline $\begin{array}{l}\text { General Ashfaq } \\
\text { Pervez Kiyani }\end{array}$ & $1(0.4)$ & $0(0.0)$ & $3(1.1)$ & $0(0.0)$ & $0(0.0)$ & $0(0.0)$ & $4(1.5)$ \\
\hline Human Rights & $3(1.1)$ & $6(2.3)$ & $1(0.4)$ & $0(0.0)$ & $2(0.7)$ & $0(0.0)$ & $12(4.6)$ \\
\hline Imran Khan & $0(0.0)$ & $1(0.4)$ & $0(0.0)$ & $5(1.9)$ & $1(0.4)$ & $1(0.4)$ & $8(3.0)$ \\
\hline ISI (Inter-Services & $1(0.4)$ & $27(10.4)$ & $4(1.5)$ & $0(0.0)$ & $0(0.0)$ & $0(0.0)$ & $32(12.3)$ \\
\hline Intelligence) & $4(1.5)$ & $12(4.6)$ & $3(1.1)$ & $2(0.7)$ & $3(1.1)$ & $1(0.4)$ & $25(9.6)$ \\
\hline Terrorism & $16(6.1)$ & $94(36.2)$ & $12(1.2)$ & $41(15.8)$ & $94(36.3)$ & $2(0.7)$ & $259(100.0)$ \\
\hline Grand Total & & & & & &
\end{tabular}

It is relevant to highlight here that coverage in favour of political leadership was found significantly greater in comparison of pro-military leadership coverage. In other major sub themes namely relations with the United States, UK and India, the ratio of anti-military contents was found significantly greater in comparison of anti-civilian representation. On a similar trend the military establishment was framed with negative tone as all coverage was against them in the context of Kerry Logar bill. In the category of Mumbai attacks, military leadership has been represented with negative frames and criticized whereas issue of Memo Gate also has been covered within same paradigm of against to military leadership. If we analyze the coverage in context of anti-civilian representation, then it can be noted that corruption and political leadership categories have been represented negatively to civilian leadership with ratios of $8.5 \%$ out of $9.3 \%$ and $29.1 \%$ out of $30 \%$ items respectively. Greater 
Portrayal of civil and military leadership of Pakistan: Content analysis of Newspapers of UK ...

pro-civilian coverage has been calculated in the category relations with United States rather than relations with India. Last but not the least, the military leadership was depicted with negative tone in the entire context with ratio of 111 (42.9\%) out of total 259 (100\%) selected sample in the four selected newspapers of UK and USA.

Table-5: Themes/subtopics wise representation of civil \& military leadership

\begin{tabular}{|l|c|c|c|c|c|c|c|}
\hline & \multicolumn{5}{|l|}{ Representation of civil and military leadership } & \\
\hline $\begin{array}{l}\text { Themes/subtopics of } \\
\text { published items }\end{array}$ & $\begin{array}{l}\text { Pro } \\
\text { military } \\
\mathrm{N}(\%)\end{array}$ & $\begin{array}{l}\text { Anti- } \\
\text { military } \\
\mathrm{N}(\%)\end{array}$ & $\begin{array}{l}\text { Neutral } \\
\text { military } \\
\mathrm{N}(\%)\end{array}$ & $\begin{array}{l}\text { to } \\
\text { Civilian } \\
\mathrm{N}(\%)\end{array}$ & $\begin{array}{l}\text { Anti } \\
\text { civilian } \\
\mathrm{N}(\%)\end{array}$ & $\begin{array}{l}\text { Neutral } \\
\text { civilian } \\
\mathrm{N}(\%)\end{array}$ & $\begin{array}{l}\text { to } \\
\text { Total } \\
\mathrm{N}(\%)\end{array}$ \\
\hline Corruption & $1(0.4)$ & $0(0.0)$ & $0(0.0)$ & $1(0.4)$ & $22(8.5)$ & $0(0.0)$ & $24(9.3)$ \\
\hline $\begin{array}{l}\text { Relations with the } \\
\text { United States }\end{array}$ & $1(0.5)$ & $22(8.5)$ & $3(1.1)$ & $9(3.4)$ & $2(0.8)$ & $2(0.8)$ & $39(15.0)$ \\
\hline Relations with India & $4(1.5)$ & $15(5.8)$ & $1(0.4)$ & $4(1.5)$ & $0(0.0)$ & $0(0.0)$ & $24(9.2)$ \\
\hline $\begin{array}{l}\text { Exile phase of } \\
\text { leadership }\end{array}$ & $0(0.0)$ & $15(5.8)$ & $0(0.0)$ & $3(1.1)$ & $2(0.8)$ & $0(0.0)$ & $20(7.7)$ \\
\hline Relations with UK & $1(0.4)$ & $4(1.5)$ & $0(0.0)$ & $0(0.0)$ & $2(0.8)$ & $1(0.4)$ & $8(3.1)$ \\
\hline $\begin{array}{l}\text { Memo gate } \\
\text { Kerry Logar bill }\end{array}$ & $0(0.0)$ & $31(12.0)$ & $0(0.0)$ & $1(0.4)$ & $2(0.8)$ & $0(0.4)$ & $34(13.1)$ \\
\hline $\begin{array}{l}\text { Raymond Davis } \\
\text { case }\end{array}$ & $0(0.0)$ & $1(0.4)$ & $1(0.4)$ & $0(0.0)$ & $1(0.4)$ & $0(0.0)$ & $3(1.1)$ \\
\hline $\begin{array}{l}\text { Attack on Slala } \\
\text { check post }\end{array}$ & $0(0.0)$ & $3(1.1)$ & $0(0.0)$ & $0(0.0)$ & $0(0.0)$ & $2(0.8)$ & $5(1.9)$ \\
\hline $\begin{array}{l}\text { Closure of NATO } \\
\text { supply route }\end{array}$ & $0(0.0)$ & $0(0.0)$ & $0(0.0)$ & $2(0.8)$ & $1(0.4)$ & $1(0.4)$ & $4(1.5)$ \\
\hline $\begin{array}{l}\text { Mumbai attack } \\
\text { Political leadership }\end{array}$ & $1(0.4)$ & $1(0.4)$ & $0(0.0)$ & $2(0.8)$ & $73(29.1)$ & $1(0.4)$ & $78(30.1)$ \\
\hline $\begin{array}{l}\text { Missing people's } \\
\text { case }\end{array}$ & $0(0.0)$ & $4(1.5)$ & $0(0.0)$ & $0(0.0)$ & $0(0.0)$ & $0(0.0)$ & $4(1.5)$ \\
\hline Grand Total & $8(3.1)$ & $111(42.9)$ & $5(1.9)$ & $23(8.9)$ & $105(40.5)$ & $7(2.7)$ & $259(100.0)$ \\
\hline
\end{tabular}

The above table- 6 represents overall representation of Pakistan through commutative coverage of British and American newspapers in contexts of major categories, themes/sub-topics and both regimes of Pakistan Peoples Party (PPP). In major subjects, unfavourable representation was given to Pakistan in contexts of Mr. Asif Ali Zardari and Benazir Bhutto whereas favourable representation to Pakistan in these two categories has been calculated 6.2 percent and 3.9 percent out of total $37.9 \%$ and $16.6 \%$ items respectively. It is pertinent to mention here that army leadership has been represented negatively to frame in Pakistani context as category inter-services intelligence (ISI) has calculated towards greater unfavourable representation of Pakistan with ratio of $27(10.4 \%)$ items out of $32(12.3 \%)$ news for this category. On a similar trend, in context of terrorism, Pakistan has been represented unfavourably. Through analysis of major subject wise coverage effect in creating overall image of Pakistan, it can be seen that Pakistan has been framed unfavourable with two-third majority of negative news out of total 259 items in all categories. 
Table-6: Civil \& military leadership representation in different areas and overall impression of Pakistan

\begin{tabular}{|c|c|c|c|c|}
\hline \multirow[b]{2}{*}{ Areas } & \multicolumn{3}{|c|}{ Overall Impression of Pakistan } & \multirow[b]{2}{*}{$\begin{array}{l}\text { Total } \\
\mathrm{N}(\%)\end{array}$} \\
\hline & $\begin{array}{l}\text { Favourable } \\
\mathrm{N}(\%)\end{array}$ & $\begin{array}{l}\text { Unfavourable } \\
\mathrm{N}(\%)\end{array}$ & $\begin{array}{l}\text { Neutral } \\
\mathrm{N}(\%)\end{array}$ & \\
\hline \multicolumn{5}{|l|}{ Subjects of published items } \\
\hline Asif Ali Zardari & $16(6.2)$ & $78(30.2)$ & $4(1.5)$ & $98(37.9)$ \\
\hline Benazir Bhutto & $10(3.9)$ & $32(12.3)$ & $1(0.4)$ & $43(16.6)$ \\
\hline Corruption & $3(1.1)$ & $21(8.1)$ & $0(0.0)$ & $24(9.2)$ \\
\hline Democracy & $3(1.1)$ & $8(3.1)$ & $2(0.8)$ & $13(5.0)$ \\
\hline General Ishfaq Pervez Kiyani & $1(0.4)$ & $0(0.0)$ & $3(1.1)$ & $4(1.5)$ \\
\hline Human Rights & $4(1.5)$ & $7(2.7)$ & $1(0.4)$ & $12(4.6)$ \\
\hline Imran Khan & $1(0.4)$ & $4(1.5)$ & $3(1.1)$ & $8(3.0)$ \\
\hline ISI (Inter-Services Intelligence) & $1(0.4)$ & $27(10.4)$ & $4(1.5)$ & $32(12.3)$ \\
\hline Terrorism & $5(1.9)$ & $18(6.9)$ & $2(0.8)$ & $25(9.6)$ \\
\hline Total & $44(17.0)$ & $195(75.3)$ & $20(7.7)$ & $259(100.0)$ \\
\hline \multicolumn{5}{|l|}{ Themes/Sub topics } \\
\hline Corruption & $3(1.1)$ & $21(8.1)$ & $0(0.0)$ & $24(9.3)$ \\
\hline Relations with the United States & $11(4.2)$ & $18(6.9)$ & $10(3.9)$ & $39(15.0)$ \\
\hline Relations with India & $18(6.9)$ & $5(1.9)$ & $1(0.4)$ & $24(9.2)$ \\
\hline Exile phase of leadership & $3(1.1)$ & $17(6.6)$ & $0(0.0)$ & $20(7.7)$ \\
\hline Relations with UK & $2(0.8)$ & $5(1.9)$ & $1(0.4)$ & $8(3.0)$ \\
\hline Memo gate & $11(4.2)$ & $23(8.9)$ & $0(0.0)$ & $34(13.1)$ \\
\hline Kerry Logar bill & $0(0.0)$ & $3(1.1)$ & $0(0.0)$ & $3(1.1)$ \\
\hline Raymond Davis case & $0(0.0)$ & $2(0.8)$ & $1(0.4)$ & $3(1.1)$ \\
\hline Attack on Slala check post & $0(0.0)$ & $4(1.5)$ & $1(0.4)$ & $5(1.9)$ \\
\hline Closure of NATO supply route & $2(0.8)$ & $1(0.4)$ & $1(0.4)$ & $4(1.4)$ \\
\hline Mumbai attack & $1(0.4)$ & $12(4.6)$ & $0(0.0)$ & $13(5.0)$ \\
\hline Political leadership & $3(1.1)$ & $74(28.5)$ & $1(0.4)$ & $78(30.1)$ \\
\hline Missing people's case & $2(0.8)$ & $2(0.8)$ & $0(0.0)$ & $4(1.5)$ \\
\hline Total & $56(21.6)$ & $187(72)$ & $16(6.3)$ & $259(100.0)$ \\
\hline \multicolumn{5}{|l|}{ Civilian Government } \\
\hline Asif Ali Zardari tenure as President & $44(17.0)$ & $195(75.2)$ & $14(5.4)$ & $253(97.6)$ \\
\hline $\begin{array}{l}\text { Benazir Bhutto's second term as } \\
\text { premier }\end{array}$ & $1(0.4)$ & $5(1.9)$ & $0(0.0)$ & $6(2.3)$ \\
\hline Total & $45(17.3)$ & $200(77.2)$ & $14(5.4)$ & $259(100.0)$ \\
\hline
\end{tabular}

In other significant themes namely the relations with the United States, UK, and forced or selfadopted exile of political leadership the ratio of unfavourable frames was found significantly and dominantly greater in comparison of favourable items. The issue of Memo gate further adds salt to the injuries of Pakistan as 8.9 percent coverage out of 13.1 percent in this theme was not in favour of the leadership as 23 out of 34 selected sample cultivated negative impression on larger scale. With similar ratio of 4.6 percent Pakistan was held responsible for tragic incident of Mumbai attack and framed as harbouring terrorism and directly involve in state sponsor terrorism, as 12 stories were found unfavourable out of total sample of 13 items on this sub theme. On similar pattern the ratio of unfavourable coverage was overwhelmingly 
Portrayal of civil and military leadership of Pakistan: Content analysis of Newspapers of UK ...

found greater in the sub themes of political leadership, attack on Salala check post and Mumbai Attack with ratios of 28.5, 1.5 and 4.6 percent respectively. Almost two-third majority of unfavourable coverage to Pakistan was given in four selected mainstream newspapers of UK and USA in all sub-categories. In the civilian government tenures, Mr Zardari occupied first rank with negative coverage of two-third with score of 195 out of total sample frame of 253 as comparatively mentioned in the last section of the table-6. Mr Asif Ali Zardari's tenure superseded Benazir Bhutto with almost one fourth favourable coverage and similar patterns were explored regarding the neutral representation of Pakistan with ratio of more than one fifth neutral representation in the four selected newspapers.

Overall representation of mainstream newspapers of UK and USA was against military leadership of Pakistan that supported first hypothesis of this research. The second hypothesis of this research has predicted pro-civilian representation higher than the military leadership and the assumption came true as in all categories it can be seen that greater pro-civilian coverage was calculated in three selected newspapers except the daily Telegraph in which the pro-military representation was slightly greater as compared to pro civilian coverage in the same newspaper. The third hypothesis claimed that Benazir Bhutto on her second term as premier would be portrayed in more unfavourable frames in comparison of her self-exile phase. This prediction came true as she was dominantly portrayed (5\%) with blend of negativity in comparison of his self-exile phase $(2 \%)$ of total sampled items. Fourth hypothesis of this research predicted more negative representation of Mr. Asif Ali Zardari before in power as compared to while his five-year term as elected president of the country. This assumption came true as the ratio of his negative coverage was found relatively greater before in power phase (48\%) in comparison of while in power phase which was calculated 39 percent. The fifth hypothesis of this research claimed more negative representation of military leadership as compared to civilian leadership in category of terrorism and the data found that almost 4.6 percent coverage on the said issue was found against military leadership in the category of terrorism while the ratio of anti-civilian was just 1.1 percent out of 9.6 percent total sampled items in this category. The last assumption has predicted overall unfavourable representation of Pakistan on the basis of cumulative critical representation of civil and military leadership and hypothesis was strongly supported with the figures of (Table.6) as overall impression of Pakistan in all the categories has created greater in negative tone in British and American print media during both tenures PPP.

\section{Conclusion}

The research has owed to investigate Pakistani civil and military leadership representation during both tenures of Pakistan Peoples Party (PPP) from 1995 to 1996 and September 2008 to 2013 in four mainstream newspapers of UK (Telegraph, Guardian) and USA (New York Times, Washington Post). The trend of representation in the context of location of story was explored that almost half of the total stories originating from the UK, the US and India were against the military leadership. On the other hand, more than one-third stories originating from Pakistan were published with anti-military tone. On contrary it was opposite in case of story originating from UK as pro military contents were higher from items in support of civilian leadership with slight difference on comparative basis. It is significant to highlight here a common trend among the countries as found that cumulative ratio of anti-military establishment representation was dominantly higher in comparison of the items against civilian leadership. In the context of pro-military leadership items, among all primary sources, the 
stories based on Pakistani officials as primary source ranked first among the published items in support of military establishment whereas Indian officials-based stories were at the bottom number. On the other hand, the stories relied on Indian officials as primary source were found anti-military establishment of Pakistan, superseding other sources.

\section{References}

Abidullah, J. (2003, August 27). Newsweek spreading hate. Weekly Nida-e-Khilafat Lahore. Ali, S. \& Khalid, M. (2008). US mass media and Muslim world: Portrayal of Muslim by Newsweek and Time (1991-2001). European Journal of Scientific Research, 21(4), 554-580.

Ali, Z., Jan, M., \& Saleem, N. (2013). Portrayal of Pakistan by US leading news magazines. $\begin{array}{llll}\text { Science International } & \text { Lahore, 25(4), }\end{array}$ https://go.gale.com/ps/i.do?id=GALE\%7CA362017055\&sid=googleScholar\&v=2.1 $\underline{\text { \&it}=r \& l i n k a c c e s s=a b s \& i s s n=10135316 \& \mathrm{p}=\mathrm{AONE} \& \mathrm{sw}=\mathrm{w} \& \text { userGroupName }=\text { anon }}$ \%7E914551f1

Amin, T. (1994). Pakistan in 1993: Some dramatic changes', Asian Survey, 34(2). 191-199. https://doi.org/10.2307/2645122

Ayoub, U., \& Ahmed, T. (2013). Portrayal of Pakistan- relationship with reference to drone strikes on Waziristan in the editorial of Dawn and the Nation: A Comparative study. Academic Research International, 4(6), 56-64. http://www.savap.org.pk/journals/ARInt./Vol.4(6)/2013(4.6-07).pdf

Baker, P. (2010). Representations of Islam in British broadsheet and tabloid newspapers 19992005. Journal of Language and Politics, 9(2), 310-338. https://doi.org/10.1075/jlp.9.2.07bak

Berlin, P, D. (2001). Civil military relations in Latin America: New analytical perspectives. University of North Carolina.

Carr, J., \& Haynes, A. (2015). A clash of racialization: The policing of 'race' and of antiMuslim racism in Ireland. Critical Sociology, 41(1), 21-40. https://doi.org/ $\underline{10.1177 / 0896920513492805}$

Dorogi, T. 1. (2001). Tainted perceptions: Liberal-democracy and American popular images of China. University Press of American.

Entman, R. M. (1993). Framing: Toward clarification of a fractured paradigm. Journal of Communication, 43, 52-57.

Falkheimer, J, Olsson, E, K. (2015). Depoliticizing terror: The news framing of the terrorist attacks in Norway, 22 July 2011. Media, War \& Conflict, 8(1) 70-85. https://doi.org/10.1177\%2F1750635214531109

Ghareeb, E. (1983). Split vision. The portrayal of Arabs in American News Media. American Arab Affairs Council.

Ghumman, S, Ryan, A, M. (2013). Not welcome here: Discrimination towards women who wear the Muslim headscarf. Human relations, 66(5), 671-698. https://doi.org/0.1177/0018726712469540

Gilewicz, M. (2012). The construction of Muslim community and British Muslim identity in two British Muslim newspapers. Doctoral Dissertation, University of Aberdeen. http://digitool.abdn.ac.uk:80/webclient/DeliveryManager?pid=196303

Haqqani, H. (2005). Pakistan between Mosque and Military. Carnegie Endowment for International Peace. 
Portrayal of civil and military leadership of Pakistan: Content analysis of Newspapers of UK ...

Hasan, N. L. (2007). Beyond the "oppressed veiled Muslim woman": Breaking barriers, bridging differences and creating dialogues. Master's Thesis, Universiteit Utrecht. http://dspace.library.uu.nl:8080/handle/1874/22803

Huntington, S. (1995). Reforming civil - military relations. Journal of Democracy, 6(4), 9-17. https://doi.org/10.1353/jod.1995.0067

Kaleem, R. (2015). Civil military relations during Pakistan People's Party 4th Regime from 2008 to 2013. International Journal of Humanities and Social Science, 5(1), 187-196.

Khan, M. A. \& Imran, F. (2011). Treatment of Pakistani elite press about government activities against war on terror: A media conformity approach. European Journal of Social Sciences, 19(3), 331- 341.

Lakhani, S. (2008). From orientalism to post colonialism: producing the Muslim woman. (Master's Thesis). McGill University. http://digitool.library.mcgill.ca/thesisfile116128

Leskó, D. (2013). The Image of Islam in the United States post 9/11. Doctoral Dissertation, University of Debrecen. http://hdl.handle.net/2437/161686

Milinković, A. (2015). Muslim women in the media after 9/11. A content analysis of the American and British digital media between 2001 and 2002. Doctoral Dissertation, University of Iceland. http://hdl.handle.net/1946/20234

Mora, L. (2013). Rescuing Muslim women from or by sharia? Islam vs. women's rights: Framing of the Dutch sharia debate by the media in 2012. Master's Thesis, Universiteit Utrecht. http://dspace.library.uu.nl:8080/handle/1874/281818

Munoz, G, M. (2005). Islam's women under Western Eyes. https://www.islamonline.net

Narayana,U, \& Kapur, P.(2011). Indian media framing of the image of Muslims an analysis of news coverage of Muslims in English Newspapers of India. Media Asia, 38(3), 153162. https://doi.org/10.1080/01296612.2011.11726895

Rasul, A., \& McDowell, S, D. (2015). Images of oppression, The Journal of International Communication, 21(1), 21-37. https://doi.org/10.1080/13216597.2014.987798

Raza, M. R., Akbar, M. W. (2012). Image of President Asif Ali Zardari as portrayed by Daily Dawn and News: A discourse analysis of editorials. Journal of Mass Communication and Journalism, 2:113. https://doi.org/0.4172/2165-7912.1000113

Ruigrok, N., \& Atteveldt, W. V. (2007). Global angling with a local angle: How U.S., British, and Dutch Newspapers frame global and local terrorist attacks. Press/Politics, 12(1), 68- 90. https://doi.org/10.1177/1081180X06297436

Safdar, A., Budiman, A. M., Binti, N., \& Hamid, A. (2014). Media conformity to foreign policy: Coverage of war on terror by the British press. Journal of research and society of Pakistan, 51(1), 1-21. http://pu.edu.pk/images/journal/history/PDFFILES/12v51_No1_14.pdf

Semati, M. (2010). Islamophobia, culture and race in the age of empire. Cultural Studies, 24(2), 256-275. https://doi.org/10.1080/09502380903541696

Shafqat, S. (1997). Civil Military Relation in Pakistan from Zulfiqar Ali Bhutto to Benazir Bhutto. Westview Press.

Sheikh, M. (1991). The Kashmir conflict: The United Sates policies and portrayal of issues in the New York Times. Message International, 15(3).

Sheikh, M. (1995). Image of Iran in Western Media. Iran Shenasi, an International Quarterly Journal, (4).

Sheikh, M. (1997). Editorial treatment of United States foreign policy in the New York Times (1980-90). The case of Pakistan. Development Security. 2.

Sheikh, M. (1998). Image of Pakistan in the New York Times, (1980-90). Pakistan Defense 
Review, 7(1).

Sheridan, L, P. (2006). Islamophobia pre- and post-September 11th, 2001. Journal of Interpersonal Violence, 21(3), 317-336. https://doi.org/10.1177\%2F0886260505282885

Siraj, S. A. (2007). Image of Pakistan in the US media: Exploring news framing. www.hec.gov.pk

Suleiman, M. W. (1983). The effects of American perceptions of Arabs on Middle East issues. Split vision: The portrayal of Arabs in the American media, 337-344.

Syed, A. (2009). Buzzing: Post-9/11 Muslim male identity, stereotypes, and beehive metaphors. Master's Thesis, University of New South Wales. http://handle.unsw.edu.au/1959.4/44571

William, P. (2001, August 15). Pentagon alone calls the shots. Dawn (Karachi).

Zundel, E. (2005). The West, war and Islam. https://www.radioislam.com 